\title{
Partnering for Education Finance in Nigeria
}

\author{
Prof. Charles M. Ogbodo \& Dr. Sunday I. Efanga \\ Department of Curriculum Studies Educational Management and Planning \\ University of Uyo, Uyo, Nigeria \\ E-mail: drefanga200@gmail.com
}

Received: Jan. 20, 2014 Accepted: February 14, 2014 Published: February 14, 2014

doi:10.5296/jse.v4i1.4977～URL: http://dx.doi.org/10.5296/jse.v4i1.4977

\begin{abstract}
Education financing has been an intractable problem especially in developing countries. In Nigeria it is currently a burning issue as concerned stakeholders are expressing alarm over what has now become a crisis. This paper addresses the issues of partnering in funding education as a way of bringing about educational development. It examines the history of education financing in Nigeria highlighting the partnerships that were formed in this regard. It also reviews education funding patterns in India and the United States of America drawing relevant lessons from Nigeria. The paper also analyses the characteristics of education as a good means of finding justification for recommending a tripartite funding model for education in Nigeria.
\end{abstract}

Keywords: Partnering, Education Financing, Educational Development 


\section{Introduction}

Educational development has been a goal towards which all nations, all civilizations press since the beginning of human society. It is not a once achievable goal and this means no society, no nation can afford to stop as it were at any point in time, beat its chest as it were, and say it has achieved the goal of educational development. Educational development is measured in terms of how far the society is moving towards that goal. What are the educational needs of the society in terms of cognitive needs (Knowledge). Skills needs and affective (attitudinal) needs and then how effectively and efficiently the society is deploying its educational structures to meet these needs both qualitatively and quantitatively. That is educational development.

These needs are intractable and dynamic. They keep changing and the progressive and successful society must ensure that the education system responds intandem with these changes. Herein lies the challenge of educational development. In Nigeria, education has been growing rapidly and this has been largely due to the growth in population especially of the school age. We now have more schools of all types at all levels of the educational system. But growth in education due to growth in population does not ip-so-facto translate into educational development. In other words, "growth" does not necessarily mean “development”.

To experience educational development, money is needed. Much of it (Efanga, 2013). Money is a resource input which education utilizes a great deal. It is a very significant input because with it other important resource inputs such as labour (teachers) ideas and materials can be procured.

The provision of adequate funding for educational development has become a problem in virtually all countries and more so in a country like Nigeria which is still developing its structures in all spheres of societal life. Partnering, therefore suggests there is a "funding load" which might be too heavy for one head (government) to carry and that the load may require partners' "heads" to carry it effectively for educational development.

In this paper, we shall look at the history of education finance in Nigeria with particular stress on the partnerships in funding that were formed in early times. We shall also examine the education funding models of a few countries and see what we can learn from them. We shall then see the partnerships we can form in education financing in Nigeria and lastly suggest an appropriate education finance mode for Nigerian educational system.

\section{History of Education Finance in Nigeria}

When western education was introduced in Nigeria in the mid $19^{\text {th }}$ century, it was essentially a missionary enterprise. The funding of this education was the responsibility of the various missions who had to rely on their home missions for financial support (Fafunwa, 1974). At this time the colonial administration was indifferent to the education of the colonies and did not provide for education in its annual estimates (Adesina, 1960). 
However, owing to incessant demands from the missions, who were finding it difficult to fund education alone, the colonial government in Lagos made attempts to assist some of the missions. In 1870, it earmarked the sum of 300 pounds to assist these missions (Fafunwa, 1974). It is important to note that this budgetary provision was never actually released due to lack of funds. In 1872 the sum of 1000 pounds was again earmarked but later reduced to 330 pounds and later to 30 pounds which was later shared to the missions.

As a result of this obvious lack of interest on the part of colonial government to assist in funding education, an association was formed with the objective of raising funds in support of education especially primary education. In the parlance of today the organization would be called an NGO (Non Governmental Organization). One can see here, the very beginning of partnering for educational development. The initiative came not from an indifferent colonial government but from ordinary private citizens who felt the need to partner with impecunious missions to provide basic primary education to a largely illiterate society.

The first education ordinance was promulgated in 1887 and it provided for the first time a legal commitment on the part of government to become a major partner in the development of education in the Lagos colony. This led to the dual control of education whereby the government owned and directly funded some schools, and gave grants in aid to others owned by voluntary agencies such as the missions.

From this period onward there has been a steady increase in government expenditure on education. In 1889, government expenditure on education was 942.6 pounds and this rose to 1,562 pounds in 1890 (Taiwo, 1975).

Between 1918 and 1952 educational expenditure grew from 1 to 16.9 percent of total government expenditure. The national economy did not grow by as much rate during the same period and so this was a remarkable increase. The regional provisions of the 1954 constitution decentralized education funding as the central government and the three regional governments now shared the responsibility of funding education. This led to further increases in public expenditure in education between 1953 and 1962. Public expenditure on education between the period grew from 9.7 million pounds in 1953 to 41.7 million in 1962 (Adesina, 1982).

The constitution changes of 1954 enabled the western region to embark on the first attempt at Universal Primary Education in 1955. The government went at it alone. This led to enormous increase in that region's expenditure on education. In 1955, it budgeted 5.4 million pounds for education. Nearly 90 percent of this amount was spent on primary education. The Eastern Region tried out its own Universal Primary Education in 1956 but had to abandon the scheme in its second year due to financial difficulties. The north could not even contemplate the scheme because of the enormous number of school age children that would have been provided for. These regional efforts at UPE marked an era of rapid increase in educational expenditures in Nigeria.

With the end of the Nigerian civil war in 1970 a new dimension in public funding for education was added. That was the state take-over of primary and secondary schools from 
voluntary agencies. This trend was started by the defunct East Central State in 1971 and by the end of that decade, most states of the Federation especially in the southern parts of the country had followed suit. This acquisition greatly increased the government burden in education. It was like the government saying in effect that it did not want partnering in educational development. In 1972 the responsibility for higher education which was in the concurrent legislative list in the 1963 constitution was reversed by decree to the Federal Government. The Federal Government then took over all existing State Universities and set about establishing new ones. This further increased the level of government financing of education.

The government was able to expand its activities in the education sector during the 1970s because of the increased revenue from oil. The Gross Domestic Product (GDP) grew from 5 percent in the 1960s to 10.3 percent by the 1977 fiscal year (central bank Report, 1978). The launching of the UPE by the Federal Government in 1976 further escalated public expenditure on education. The Federal Government indicated it would assume full financial responsibility for the programme nationwide, in all its ramifications (Ozigi and Canham, 1979). Although the other arms of government were later asked to take over the financing of some aspects of the program, it still marked a quantum rise in federal funding for education (Ogbodo, 1995).

Other public cost escalating measures were also taken which increased public spending on education. These were reductions in tuition fees for secondary education throughout the country to (10.00) ten naira, free teacher education and abolition of tuition fees in the universities. The financial implications of these measures made education to rank fifth in quantum of financial investment in third National Development Plan 1975-1980 (Third National Development Plan, vol.1, 1975). Out of 30 billion naira set aside for capital investment in all sectors, education got 2.5 billion naira.

With the inception of the Second Republic in 1979 however, the Federal Government realizing that its financial commitment in public education was getting too heavy withdrew direct subsidy for primary education and transferred the responsibility to the Local governments. That effectively marked the end of free education in most states of the Federation.

Despite these measures, however, public expenditure on education has continued to rise. From the 1980s following the restoration of higher education on concurrent legislative list, state governments have continued to establish universities and other institutions of higher learning. As we speak, all the 36 states of the Federation have their own universities. There are also 36 Federal Universities giving a total of 114 public universities. There are 98 Federal and State Polytechnics/Monotechnics and 86 Colleges of Education. (NUC, 2012). These figures are constantly changing as more approvals are granted to new institution on a regular basis. The extant policy encourages this trend. In fact Nigeria has the largest and most complex higher education system on the continent. This means that, public sector investment in education will continue to rise in the foreseeable future. 
In 1999 on coming into office the civilian administration embarked on the Universal Basic Education (UBE) programme. This marked a significant re-entry by Federal Government into the area of funding for primary education in the country.

The UBE Act of 2004 provides that the Federal government should provide a block grant of not less than $2 \%$ of its Consolidated Revenue Fund to finance basic education. It also provides that states, Local governments and local and International donor grants should also be involved as partners in funding basic education FRN, (2004).

The Federal, State and Local governments have been making considerable financial allocations to the education sector in recent times. Despite all these, however, there is abundant evidence of under-funding and under-investment at all levels of the education system. Infrastructural facilities in the public schools are either inadequate or decaying or both. Equipment and other teaching and learning tools are grossly inadequate and library facilities are also inadequate and begging for improvement in virtually all public institutions that require them.

For the Universities and other higher institutions the funding situation has reached a crisis point. Virtually all Federal Universities are operating at various levels of insolvency. The Federal government appears unwilling to radically expand its funding of education especially higher education to a level that would make for real educational development. In June 2013, lecturers in all public Universities embarked on an indefinite strike over the failure of the Federal government to implement the 2009 agreement with their union. The strike lasted for five months. The main issue in dispute was funding for universities. The government had agreed to raise the level of public funding of the universities to a certain agreed level. It failed to do this citing shortfalls in projected revenue during the period.

The reason for this is not hard to find. Until recently education dominance of the national budgets of most developing countries had been taken for granted and had gone largely unchallenged. Public expenditures on education absorb between three and five percent of Gross National Product (GNP) in most developing countries (World Bank, 1983).

In Nigeria, this is no longer so. Health, agriculture, energy, road, construction and public works, defence and governance have now emerged as important consumers of public funds. The cost of governance has exceeded government spending on education. These areas also claim that they too not education alone contribute to economic growth. They have proved to be tough competitors with education in the race for public funds.

It appears that the Nigerian government is still operating under the influence of the World Bank which exerted pressure on developing countries by de-emphasizing the role of higher education, in development in Africa. The World Bank pressurized countries to adopt policies that cut budgets to higher education and re-direct those funds to the school sector.

Ironically this approach was only recommended for Africa ahnd not the Western world. The World Bank arguments were based on the rate of return studies that indicated higher rates of returns from investments in the school sector (primary and secondary), than in the higher education sector. These studies indicated $10.8 \%$ rate of returns for higher education compared 
with 19\% for primary education (Psacharopoulos 1986). This thinking has since shifted as more and more studies now recognize the role higher education plays in development and poverty reduction. (World Bank UNESCO Task Force Report 2000). There is therefore no economic justification for restricting funds for higher education and emphasizing only basic education.

It has become clear from our review that government is unwilling and or unable to fund education alone. Partnering has therefore become an imperative. How should this be? Before we delve into that let us take a cursory look at how a sample of countries are managing to finance their education and see what we can learn from them.

\section{India}

India is a Federation of states just like Nigeria. She also has a similar colonial heritage with Nigeria. It is a vast and very populous country. India's educational system is considerably developed and supports a thriving economy with a robust military industrial complex. Until 1977 when the constitution was amended to bring education under the concurrent legislative list, education was a matter for the individual states. From 1977 however the Federal government came in to partner with the states in the provision of education (Afe, 2001).

Federal participation in education financing in India comes in the form of grants in aid made to the states. Grants are also given to education during specific development plan periods through the planning commission. The Federal and State governments are not the only partners for educational development in India. A World Bank study conducted in 1986 revealed that a major source of funds for India's education comes from the private sources (World Bank, 1986). The study shows that private funding for education in India is more than that of the Federal and state governments combined. Between 1975 and 1980 private sector funding accounted for 64.20 percent of total national expenditure on education. Public sector funds accounted for only 35.80 percent. Education in India accounts for only 10 percent of national budget but she has developed a progressive private sector system of financing education. In India therefore the partnership is between the Federal and State governments and the private sector. It is important to add that India's education especially higher education is sufficiently developed to attract foreign students whose fees and other expenditure yield considerable earnings to India.

\subsection{United States of America (USA)}

The United State has a well decentralized system of education financing and control. The Federal, State and Local councils each has varying levels of financial, administrative and regulatory responsibilities (Ocho, 2001). Although private sector funding for education is very well pronounced in the United States, yet the government fully conscious of the strategic role education plays in national life and international competitiveness continues to maintain active interest in educational development. Even in the U.S education is not completely deregulated. Government still subsidizes education even in private educational establishments. There is government assistance for indigent students so that no one who is educable can be denied education simply because of poverty. 
The private sector is a very active player in U.S. education especially at the tertiary level. Large corporations and foundations fund researches in strategic areas and the universities both public and private compete for these available grants. The military industrial complex in the U.S. thrives on researches funded by the government and the private sector and carried out in universities and other research centres. In the United States therefore there is a thriving partnership between the public and private sectors in the provision of education. Religious organizations also contribute to the financing of education in the U.S. They establish and run what is known as parochial schools and those who choose such education attend such schools. Public funding however is not made available by law to such schools.

The two examples of India and United States would do for the purpose of this paper. However before going into what funding arrangement or education finance model would be appropriate for Nigeria, it is important to examine the nature of education as an economic good or product vis-à-vis the investments that go into its production and how it is consumed. That would provide a rational economic basis for any partnership for financing education in Nigeria.

\subsection{Education as economic goods}

The economic characteristics of education as a good have implications for education finance. Education is neither public goods nor private goods. It is neither consumption nor investment goods. It is actually a mixture of the four. Private goods are produced and should be produced by private enterprise. For public goods, their financing should rest with the government. If education were to be purely private goods, it should have been left for private enterprise to determine what to produce and the volume of its production in turn would be determined solely by demand. Public goods have externalities. This means that the benefits from such goods do not accrue individually or separately to the individuals but rather to society as a whole. The presence of such externalities therefore justify government intervention in their procurement.

What it means is that such goods are not appropriable by individuals and one person's consumption of those goods does not adversely affect another person's consumption of the same goods. Since public goods are not appropriable, they cannot be purchased by private individuals and so private enterprise cannot produce them because they cannot sell them. The best example of public good is national defence. In the case of education however the externalities it yields are partial in that although society as a whole derive benefits from its consumption, individual recipients benefit as well and in most cases even more. In other words education is partially appropriable and one individual's consumption of it may hamper another person's consumption of it. Individuals adjust their purchases according to the direct benefits they receive or expect to receive and do not consider externalities. Additional government finance is therefore necessary to achieve optimal allocation of resources to education.

The point we are making here is that, the traditional economic argument for public finance for education is that, not only individuals but also society as a whole derive benefits from the consumption of education. It is often believed that collective social benefits from investments 
in education exceed those accruing to individuals. Since education is indivisible and private individuals have no economic incentive to pay for more than their expected private benefits, government subsides are necessary to avoid under-investment in education.

From our analysis, it has become evident that we can justify government involvement in the procurement of education on grounds of economic efficiency. The problem however is determining the extent of this involvement. Should the government carry the burden alone or meet the private consumers halfway? In theory, the relative contributions of public and private finance to education should depend on the magnitude of the expected benefits (both economic and psychic) accruing to each party. (Jullade,, 1973). But these benefits are not easily measurable.

As a result of the difficulty in quantifying the benefits accruable to education both social and private, decisions concerning the financing of education become in practice political decisions which reflect the preferences of society and its value system. These preferences are not similar in all societies and they may and do even change within a given society and may vary according to the level of education considered. That is why in one country public share of total education expenditure may be 10 percent and in another it may be much more so. In one country you can have free primary education and fee paying secondary education and tertiary education. This means that, any kind of cost-sharing arrangement between taxpayers and the consumers of educational services can be devised.

The foregoing analyses may have helped us make a case for partnering for educational development in Nigeria. By answering the question who pays for and who benefits from education, we would invariably arrive at a rational, fair and equitable arrangement for financing public education in Nigeria.

\subsection{The Suggested Partnering Arrangement}

Unarguably, the individual consumers of education receive direct economic and psychic benefit from education. These accrue to them in the form of a stream of higher earnings arising from their consumption of education and the satisfaction and richer cultural life that results from education. Because the individual benefit from education directly he should bear some of the burden of financing education. Unless the government is able and willing to bear all the burden.

We have also seen that the individual does not fully appropriate the benefits from education. Some benefits spill-over to society because of the individuals' consumption of education. Sometimes the social benefits may even outweigh the private benefits. As a result the public should remain a major partner in the financing of education in a developing country like Nigeria. Public investment in education is crucial to direct education to areas of national need and not only areas of individual preferences. Public investment in education is also needed to bring investment in that critical area to the optimum.

The private sector is also a direct beneficiary of the output of education. They utilize the products of the educational system as labour for their own production of private goods and services. They turn inventions and discoveries from educational endeavours into profit. They 
too should partner with government and private individuals in financing public education. It is in their overriding interest to do so the present policy whereby a special tax is levied on the profit of joint stock companies and the revenue earmarked for tertiary education is a move in the right direction.

\section{(TERTFUND)}

\section{Summary/Conclusion}

In this paper, we have had an historical overview of education finance in Nigeria from colonial times to the present. We have observed that partnering for educational development is not new or alien to Nigerian education system. The authors have also taken a cursory view of the system of financing education in India, and the United States and related it to Nigeria.

Considering the economic characteristics of education as goods, we therefore make a strong case for a tripartite partnership between the public represented by the government, the private individuals who consume education and the private sector that utilize the products of education in terms of educated individuals and new knowledge. Such partnering would make for educational development which in turn would translate to economic, social and political development of Nigeria.

\section{References}

Adesina, S. (1982). Planning educational development in Nigeria. Lagos: Board of Publication.

Afe, J. O. (2001). Financing education in India. In Maduewesi, C. J. (ed), Financing education in Nigeria. Ibadan: XTM Technologies Press.

Aghenta, J. A. (1984). Towards a systems approach to planning secondary education. In Nigeria, In Adesina and Ogunsaju (eds) Secondary education In Nigeria. Ile Ife: University of Ife press.

Bloom D., Canning D., \& Chan K. (2006). Higher education and economic development in Africa. Washington D. C; The World Bank.

Fafunwa, Babs. (1974). History of education in Nigeria. Lagos: Heinemann.

Federal Government of Nigeria (FGN), Third National development Plan. Lagos: NERC

Federal Republic of Nigeria. (2004). The Compulsory, Free, Universal Basic Education Act 2004 and other Related matters, Abuja: UBE

JALLADE, Jean-Pierre. (1973). Financing of education: An examination of Basic Issue. IBRD.

Kelly, j. A. (1973). Rethinking educational financing. London: Jossy-Bass Inc.

National Universities Commission. (2012). Summary of number type and ownership of Universities in Nigeria.

Ocho, L. E. (2001). Financing educational in the United States of America. In Maduewesi, E. H. (ed), Financing education in Nigeria. Ibadan: XTM Technologies Press. 


\section{Macrothink}

Journal of Studies in Education ISSN 2162-6952 2014, Vol. 4, No. 1

Ogbodo, C. M. (1993), Public expenditure on education in Nigeria: AN historical overview. The Educational Planner, 4(1\&2); 11-14

Psacharopoloulos G., Tan J. P., \& Jimenez E. (1986). The Financing of higher education in developing countries: Exploration of policy options. Washington, D.C.: The world Bank.

Taiwo, C. O. (1975). Henry Carr: An African contribution to education. Ibadan: African University press.

The World Bank (IBRD), Annual Report. (1983). Washington, D.C. 